\title{
The Role of Strategic Management in Economic Cycles of Family Enterprises in the Process of Institutionalization
}

\author{
Abdurrahman Saridag \\ South China University of Technology, Guangzhou, China \\ Email: a.saridag@hotmail.com
}

How to cite this paper: Saridag, A. (2021). The Role of Strategic Management in Economic Cycles of Family Enterprises in the Process of Institutionalization. Open Journal of Business and Management, 9, 527-535. https://doi.org/10.4236/ojbm.2021.92029

Received: April 23, 2020

Accepted: March 2, 2021

Published: March 5, 2021

Copyright $\odot 2021$ by author(s) and Scientific Research Publishing Inc. This work is licensed under the Creative Commons Attribution International License (CC BY 4.0).

http://creativecommons.org/licenses/by/4.0/

\begin{abstract}
Family businesses in our country and in the world are an important force in the economy. Therefore, the importance of family businesses in the economy is indisputably large. But nowadays competition and globalization reduce the sustainability of family businesses. This situation firstly harms the family business and then the economy significantly. Strategic management has become a necessity in today's world where competition is increasing day by day and competition is globalized. Strategic management activities are carried out to ensure long-term success in almost all sectors. They can achieve the target and long-term achievements that they want to achieve in the near future through strategic management. The focus of this study is on the adoption of a strategic management approach to the positions that enterprises must take against the conditions arising from global competition.
\end{abstract}

\section{Keywords}

Strategy, Family Business, Strategic Management, Institutionalization

\section{Introduction}

Our world, which is experiencing a rapid change, is constantly innovating in technological and economic fields. Depending on the services and products offered every day, more differentiation is made in order to compete with competitors. In competitive environments, they have to constantly innovate and make changes in the organization, management structure, systems, human and information resources of businesses and family companies.

Family businesses are briefly defined as businesses controlled by a family. In-house practices are needed to ensure the sustainability of family businesses 
for more than two generations.

Institutionalization enables family businesses to survive longer, supports family businesses and eliminates situations that may hinder their continuity. It seems easier to implement the regular management idea required for the institutionalization of the family company with strategic management methods.

Organizations need to carefully analyze changes to achieve their long-term goals. In internal environmental analysis, strengths and weaknesses of businesses, family companies, and opportunities and threats faced by businesses in external environmental analysis can be tried to be determined. Businesses can shape their future by determining effective and innovative strategies to be successful in the long term. Competitive businesses compete fiercely with each other. It is seen that powerful businesses observe their environment better and evaluate the possibilities for their own interests.

In this study, first of all, the family business structure is included. After mentioning the necessary steps and objectives for the vision of these companies, the strategic management structure, which is the main point, was given in detail. Based on data and information from various family businesses, many details such as benefits, goals, and reasons are listed for each topic. In the light of these results, some suggestions have been made to institutions and new researchers.

\section{Family Businesses}

\subsection{The Concept of Family Businesses}

The concept of family businesses are businesses that have blood ties with each other, and are managed by one or more members of a family that are connected with marriage or adoption (Olson, Zuiker, Danes, Stafford, Heck, \& Duncan, 2003: pp. 639-666).

Family businesses constitute $65 \%-80 \%$ of the businesses worldwide. Family businesses comprise $40 \%$ of the most successful and largest companies in the world. 95\% of the businesses in our country are family businesses (Kebeci, 2011).

There are three criteria used in defining family businesses. The first is when families have a say in the control of businesses. Another is that families have a say in the management of the business, and finally, third, the ownership and leadership of the business is left to the next generations (Athanassiou \& Crittenden, 2002: p. 139).

According to Aydiner (2008), family businesses: it is defined as the establishments that are established to provide families' livelihoods or to prevent the distribution of heritage, are managed by the individual who controls the family livelihood, a large part of the management department is filled by family members, where family members are influential in decisions and where minimum two generations of family members work.

According to Findikc1 (2011), there are some common points in the family business definitions. It is possible to list them as follows:

- Family businesses are families that have established a business. 
- Family businesses, an institutional structure initiated by an individual from the family members, and then the family's business purpose.

- Family businesses are a social structure where families reflect their unique culture and traditions.

- Family businesses are the structures in which more than one family member works.

- Entrepreneurs, who usually have relatives in family businesses, are in the same majority in management.

- In family businesses, ownership belongs to the families.

- In family businesses, the affairs of families are affected by their families in their work.

- Family businesses are a union that is established for preventive purposes in the disintegration of generally found assets.

- Family businesses are usually set up to ensure the continuity of togetherness and unity.

- Family businesses are a form of business where decision makers and dominant characters are members of the same family.

- Family businesses are a form of organization that allows family members to live on their own and maintain economic unity.

\subsection{Characteristics of Family Businesses}

Family businesses have different characteristics compared to other businesses. The main elements that make up family businesses are as follows (Aydiner, 2008: p. 53).

- Blood ties between individuals are among the important criteria in determining who is responsible and who will be responsible for business management.

- The child/children of the current manager or former manager are in the management of the business.

- The current position of one of the family members in the business also has an impact on its position within the family.

Families and jobs are among the important assets of businessmen. The important difference that distinguishes family businesses from other businesses is that these two situations are intertwined. Considering this situation, it is possible to list the characteristics of the family business as follows (Findıkc1, 2011: p. 21).

- The blood link determines, among other things, who will be responsible for management.

- Children of those who are managing positions in the current or previous periods take on the management.

- Business reputation develops with the family.

- The position of one of the family members in the business determines the position of that individual in the family.

- The value of family and business is identical. 
- A link is provided between family interests and business policy.

According to Kebeci (2011), the characteristics of the family business are as follows:

- Mostly two generations of the family take part in the management of the company. The partnership between spouse, sibling, parents and child is defined as the family company.

- Business policy reflects the interests of the family. Established to protect the assets of families, the company is undoubtedly affected by family norms.

- The blood link has priority over other factors in determining personnel. Individuals with whom the business owner has affinity, mostly in his business life, he has a close relationship with top managers.

- The name of the family is linked to the name and prestige of the company. In this way, the surname plays an important role in determining the prestige of family members.

- In family businesses, employees are shown flexibility in annual leave.

\section{The Concept of Institutionalization}

Institutionalization: it does not mean leaving entirely to professional managers, giving them control, acting according to the opinions of more professional individuals than their own ideas, having too many consultants and exporting important information of the business. Institutionalization is basically the name given to the process of becoming an institution. According to Pazarcik (2004), institutionalization, is the state where businesses can become a system.

Institutionalization is the rule that certain rules dominate the relations of the family in the social system, from the life of the person to the life of the family and the institutions established by the family in all communication and interaction within the enterprises (Kebeci, 2011: p. 97).

Businesses are a form of living institution. Because they are living institutions, they have their own culture. Therefore, certain rules must be announced to the personnel in writing within the businesses in parallel with the culture of their enterprises. In this case, it is among the requirements of the institutionalization process.

According to another study, institutionalization: it defines the establishment of a system within the enterprise. Institutionalization requires all parts of the system, the roles and duties of the personnel in the business, the level and form of the relationship and interaction between family members and other employees in the system, determining how to transfer the powers and developing behavior in accordance with this situation (Karpuzoğlu, 2004).

Institutionalization; It is not that the individuals who are the managers of the boss and their family members leave the jobs to completely professional people, but on the contrary, the bosses are always in their jobs and create a collective togetherness and working spirit with other employees (Olson et al., 2003: pp. 639-666). 


\section{The Purpose of Institutionalization of Family Businesses}

One of the weaknesses of the family business is the confusion of the concept of family with the concept of business. There are many social, emotional, psychological and economic concepts that form the family, the smallest unit of society. Living, developing and functioning family structure within the framework of these concepts consists of intra-family relationships and the unique culture of the family. The concept of business, on the other hand, is a formation that is largely composed of economic interests, established for production purposes and is far from the concept of family in terms of system. The decisions taken in these two separate entities are taken on the basis of the characteristic features they contain. Regardless of their experience and abilities, family members are hired and rise within the organizational hierarchy. Sometimes, a special position is created for those individuals. However, the globalization situation and the competition, information advantages and technologies, rapid changes that have caused this situation compel the family business to give up transformation. In this case, family managers with strong and different skills, knowledge and skills are required (Pazarcık, 2004: p. 36).

In order to ensure a successful and continuing family business, it is necessary to see the future of the business and to determine the strategy to be followed and to establish the corporate structure before the events that may be faced in the future. One of the important reasons why family businesses do not succeed is inadequate management and institutionalization (Genç \& Karcığlu, 2004).

All institutions are managed in written or verbal form. Often founding entrepreneurs determined such a scheme and this situation continues to be applied until they leave the company or die.

Institutionalization appears in this case. If the rules set by the founder of the institution end with the death of the founder, unfairness will occur in the enterprise. Because of this situation, the success of the enterprise will disappear. In order to eliminate the failure situation, it would be correct to apply the concept of institutionalization in two different stages. Beforehand, it is necessary to distinguish between the concepts of business and family, and to differentiate in the form of institutionalization and institutionalization of the family (Kebeci, 2011: p. 99).

Business institutionalization is easier. This is because there are already existing rules and systems. All that is needed is to identify the deficiencies in the system and put them in a certain order. However, the institutionalization of families is not as easy as institutionalization. It is not possible for all families to be together as there is a cultural difference. For this reason, families need to create a system according to themselves.

\section{Strategic Management}

In the 1970s, the phenomenon of strategy attracts attention among the business managements. The differences in the market highlight competition. Rising 
pressure within the competitive environment has led businesses to make strategic moves. He carried out organizational works of all units in strategic management enterprises.

The rapidly occurring differences in the environment caused the enterprises to compete with each other. It is determined that it is necessary to develop effective strategies and make good use of the opportunities within the scope of business capacity and situation analysis (Kramer \& Kroon, 2020).

\subsection{Characteristics of Strategic Management}

Leadership quality is of great importance in the successful implementation of strategic management. Even the strategic thinking of the unqualified leader is limited. It is possible to list the characteristics of strategic management as follows:

- The goal of strategic management is to increase the performances in the ongoing processes, and to increase productivity and profitability. One of the most important principles of strategic management for the future is that organizations use their resources efficiently and effectively in order to provide important conditions such as sustainable competitive advantage, long-term life sustainability and gaining above average profit in the competitive field. Hereat, strategic management aimed at the vision related to the future.

- It is a phenomenon that usually occurs in senior management and generally concerns senior management. Top management in companies is the highest unit where decisions are made on behalf of the company and the executive and managing duties are performed, while the sub-unit is the unit where these decisions are implemented. Strategic planning principles created for the benefit of the company in accordance with the top management are implemented by sub-units.

- Strategic management is a form of management that allows businesses to evaluate their environment. It helps to identify strengths and weaknesses within the business. Identifying the weaknesses and strengths of an organization is one of the most important steps to be taken to make the future vision of that organization good and sustainable. Determining weaknesses and strengths and making arrangements, improvements and developments in this direction are among the most effective decisions in this way.

Other features of strategic management are given below (Leiblein \& Reuer, 2019).

- It is the top management function.

- It is about business vision.

- Enterprises represent open systems and are closely monitored in the external environment due to this situation.

- The responsibility they show to the external environment is in the public interest. It also has only social responsibility.

- In the light of this system, the necessary resources can be allocated effectively 
in order to reach the business objectives.

- All decisions made constitute the common starting point of all employees from the top unit to the bottom unit.

\subsection{Benefits of Strategic Management}

According to Çoban and Uysal (2005) that are managed with strategic management and have added economic, visionary and above-average profit power to their companies in this direction in the last 16 years, the benefits of strategic management below:

- It gives the ability to predict changing conditions.

- It clarifies the goals and approaches of the companies.

- In this system, the research process contributes to the people in the management unit.

- It offers managers benefits in clarifying the most obvious problems of the business.

- It contributes to the development of short-term planning such as communication, coordination, resource orientation and budget within the organization.

Ağlargöz (2012), on the other hand, explained the benefits it provides to the business as follows:

- It contributes to the identification and evaluation of probabilities.

- Brings objective perspectives on organizational problems.

- Allows organizations to conduct audit work comfortably.

- It reduces the negative effects of possible changes in organizations.

- Allows linking decision making processes with organizations' goals.

- It enables more efficient use of time.

- It enables communication to be conducted effectively.

- Motivated business staff to think about the future.

- Brings discipline to management.

\subsection{Strategic Management in Family Businesses}

When talking about strategic management in the family business, it is necessary to talk about the family culture, values, the relationships between the individuals in the family business, the transfer of management and the effects of the future generation's participation in the management. When the studies about family businesses are analyzed, these values have a great effect on the success of strategic management studies (Alayoglu, 2006: p. 549).

The first thing to do by the family businesses that want to establish strategic managements, their target areas should become clear and parallel to this situation, a vision must be determined and a mission that will show the reasons of the companies must be defined. In this way, it will be much easier to reach the business target (Ülgen \& Kadri, 2013).

The main goal in strategic management is to have their own future. Today, all 
businesses must be managed strategically in order to be successful.

Ultimately, family businesses are affected by both their dynamics and changes in the external environment and feel compelled to adapt to competitive conditions. Those who cannot adapt to the external environment do not succeed and it is not easy to survive. However, if they switch to strategic management, it is possible to achieve success by providing a competitive advantage compared to the companies in the external environment (Okumus, Altinay, Chathoth, \& Koseoglu, 2019).

\section{Result}

Today, significant changes have occurred in all sectors with globalization. Businesses that are most affected by these changes are the innovative approaches that will provide an advantage in the markets against their competitors, following the developments closely and making the changes within their own structure.

Strategic management is a long-term plan that companies develop in accordance with their goals and objectives in order to realize development and change.

In order for companies to live and sustain their future visions for a long time, it is important to take into account their strengths and weaknesses, rather than the sentimentality of being a family unit, it is important to act with the purpose of production and economic profit from being a company formed and managed by interdependent people. Concordantly, implementing strategic management and taking this path is one of the most important steps.

Family businesses are obliged to move away from traditional methods and develop management methods in accordance with the new order. These new forms of management also include institutionalization. Institutionalization includes the systems for solving problems in terms of family businesses. One of the important steps of this situation is the regulation and renewal of the management style.

While this research was being implemented, it had to be done in a limited area and with a limited number of participatory organizations as a result of a series of measures taken due to the new corona virus (COVID-19) outbreak. A more comprehensive study by expanding the population and sample of researchers who will turn to similar studies in the future, or a comparative study by including different family companies and businesses can be done.

\section{Conflicts of Interest}

The author declares no conflicts of interest regarding the publication of this paper.

\section{References}

Ağlargöz, O. (2012). Strategic Management and Public Relations Management. Eskişehir: Anadolu University Publishing. 
Alayoglu, N. (2006). The Role and Importance of Establishing a Fair System in the Remuneration of Family Members in the Success of Family Businesses. 2nd Family Business Congress Proceedings Book, Istanbul, 549.

Athanassiou, N., \& Crittenden, W. F. (2002). Founder Centrality Effects on the Mexican Family Firm's Top Management Group: Firm Culture, Strategic Vision and Goals, and Firm Performance. Journal of World Business, 37, 139-150. https://doi.org/10.1016/S1090-9516(02)00073-1

Aydiner, T. (2008). Investigation of the Organizational Commitment Concept of the Second Generation in Family Businesses: An Application in Family Businesses Affiliated with Izmit Chamber of Commerce. Unpublished Master's Thesis, Kocaeli: Kocaeli University, Institute of Social Sciences, Department of Business Administration.

Çoban, O., \& Uysal, E. (2005). A Strategic Approach to Cooperative Competition: Policy Benchmarking. Marmara University Recommendation: Journal of Social Sciences Institute, 6, 73 .

Findıkcı, İ. (2011). Family Businesses (Extended 4th ed.). Istanbul: Alfa Publications.

Genç, N., \& Karcioğlu, F. (2004). Problems Faced by Family Businesses and Solution Suggestions, an Application. I. Family Business Congress Proceedings Book, Istanbul, 17-18 April 2004, Publication No. 40..

Karpuzoğlu, E. (2004). Institutionalization in the Continuity of Family Companies. I. Family Business Congress Proceedings Book, Istanbul, 17-18 April 2004, Publication No. 40.

Kebeci, T. (2011). Management Approach and Institutionalization in Family Businesses. Istanbul: Second Man Publishing.

Kramer, A., \& Kroon, B. (2020). Family Capital in Family Businesses: Complementarities of Human and Social Capital. In Handbook of Research on the Strategic Management of Family Businesses (pp. 1-21). Hershey, PA: IGI Global. https://doi.org/10.4018/978-1-7998-2269-1.ch001

Leiblein, M. J., \& Reuer, J. (2019). Foundations and Futures of Strategic Management. https://doi.org/10.2139/ssrn.3396754

Okumus, F., Altinay, L., Chathoth, P., \& Koseoglu, M. A. (2019). Strategic Management for Hospitality and Tourism. London: Routledge. https://doi.org/10.4324/9781351188517

Olson, P. D., Zuiker, V. S., Danes, S. M., Stafford, K., Heck, R. K. Z., \& Duncan, K. A. (2003). The Impact of the Family and the Business on Family Business Sustainability. Journal of Busiedness Venturing, 18, 639-666. https://doi.org/10.1016/S0883-9026(03)00014-4

Pazarcık, O. (2004). Definition of Family Enterprises Institutionalization and Governance. $I$. Family Business Congress Proceedings Book, Publication No. 40, Istanbul, 17-18 April 2004.

Ülgen, H., \& Kadri, M. S. (2013). Strategic Management in Businesses (6th ed., p. 499). Business-Economy Series: 581, Istanbul: Beta Publications. 